\title{
Textile characteristics of fiber from Huacaya alpacas (Vicugna pacos)
}

\author{
Rufino Paucar-Chanca ${ }^{1, *}{ }^{\mathbb{D}} ;$ L. Alfonso-Ruiz ${ }^{2}$; B. Soret-Lafraya ${ }^{2}$; G. Mendoza- \\ Ordoñez $^{3}$; F. Alvarado-Quezada ${ }^{1}$ \\ 1 Laboratorio de Mejoramiento Genético, Universidad Nacional de Huancavelica, Av. Agricultura 319-321, \\ Paturpampa, Huancavelica, Perú. \\ 2 Departamento de Producción Agraria, Universidad Pública de Navarra, Campus de Arrosadia, s/n, 31006 Pamplona, \\ Navarra, España. \\ ${ }_{3}$ Universidad Nacional de Trujillo, Av. Juan Pablo I/ s/n. Ciudad Universitaria, Trujillo, Perú.
}

Received February 27, 2019. Accepted September 1, 2019.

\begin{abstract}
Fiber from alpacas represents a substantial component of economic output for South American countries. In this study it determined the textile characteristics of fibers obtained from Huacaya alpacas raised at the South American Camelids Research and Development Center-Lachocc (CRDC-Lachocc) located at The National University of Huancavelica (UNH). Fleece samples were obtained from the midside rib area of 74 white alpacas (42 females and 32 males) of varying ages. The Average Fiber Diameter (AFD), Standard Deviation of the Average Fiber Diameter (SDAFD), Fiber Diameter Coefficient of Variation (FDCV), Comfort Factor (CF) and Staple Length (SL) were measured as textile characteristics and related to sex and age group. Most of the fleece samples could be classified as baby alpaca fleece according to the Peruvian Technical Standard classification (231.301.2014). Sex had no influence on any textile characteristic $(p>0.05)$. Meanwhile, age affected only AFD and CF $(p<0.05)$. Together the results indicated that alpacas farmed at CRDC-Lachocc had good potential to produce high quality fibers.
\end{abstract}

Keywords: alpaca; fiber; textiles; camelids.

\section{Introduction}

Peru has the largest population of alpacas in the world and is also the largest producer of alpaca fiber based on information from the Instituto Nacional de Estadística e Informática (INEI, 2012). The alpaca population in Peru increased by $50.2 \%$ in 2017 relative to previous years. At 308,586 animals, the Huancavelica region has the third-highest concentration of alpacas in Peru, and the Huacaya breed predominates in this area (Mayhua, 2011). According to De Los Ríos (2006), at least 1.5 million people are engaged in South American camelid breeding in the Huancavelica highlands. In this area, alpacas represent an important socioeconomic resource for meat, skin, employment and especially highly valuable fiber. Alpaca farming allows extensive natural pastures, which are otherwise unsuitable for crops or other livestock, to be productive (Iñiguez and Alem, 1996). Alpacas have adapted to available dietary resources in areas where they are raised ( $\mathrm{Li}$ et al., 2008) and thus are productive even in the absence of nutritional supplementation (Moore et al., 2012).

Among South American camelids, alpacas were domesticated more than 6,000 years ago (Wheeler, 2004) and have been used for fiber production for more than 3,000 years (Wang et al., 2003; Wuliji et al., 2000). The textile industry considers alpaca fiber to be a specialty fiber, and clothes produced from alpaca fibers are highly valuable luxury items (Wang et al., 2003). Given the high market value for alpaca fiber, efforts to improve fiber quality and output have increased (Morante et al., 2011).

How to cite this article:

Paucar-Chanca, R.; Alfonso-Ruiz, L.; Soret-Laflaya, B.; Mendoza-Ordoñez, G.; Alvarado-Quezada, F. 2019. Textile characteristics of fiber from Huacaya alpacas (Vicugna pacos). Scientia Agropecuaria 10(3): 429 - 432. 
One of the most important factors to classify and determine the price of alpaca fleece is the Average Fiber Diameter (AFD). Fleece having lower AFD tends to command higher prices (Quispe, 2010). AFD is also associated with product appearance and comfort, as well as the performance of the fiber during textile processing (Mayo et al., 1994).

Fiber quality is also defined by the Standard Deviation of the Average Fiber Diameter (SDAFD), which describes the degree to which average fiber diameter values vary and Fiber Diameter Coefficient of Variation (FDCV), which describes the relative amplitude of the fiber diameter around the average value for a given fleece sample. Fibers exhibiting lower FDCV have more uniform diameters (Manso, 2011). Another important textile characteristic is the Comfort Factor (CF) that can be defined as the percentage of fibers having diameters of $<\mathbf{3 0} \mu \mathrm{m}$ in a fleece sample. Fleece that has a lower fiber diameter is perceived to be more comfortable and garments produced from fleece having a higher CF are less likely to induce itch (Quispe et al., 2013). Staple Length (SL) is an another textile feature that can be used to determine the industrial fate of the fiber, such as combing or carding (Solis, 1991).

Both quantity and quality as defined by AFD, SDAFD, FDCV and CF of alpaca fibers are affected by many internal and external factors (Lupton, 2006). Knowledge of these factors is crucial to develop strategies to improve alpaca fleece using genetic modification. In this study we examined the textile characteristics of fibers collected from alpacas farmed at CRDC-Lachocc and investigated the influence of age and sex on these characteristics.

\section{Materials and methods}

It worked with fiber samples from Huacaya alpacas farmed at the Research and Development Center of South American Camelids-Lachocc at the National University of Huancavelica. The study involved 74 animals (42 females and 32 males) that had similar feeding, handling and health conditions. The fleece samples were obtained from the middle rib area and placed in labeled polyethylene bags. Analysis of the textile characteristics in terms of Average Fiber Diameter (AFD), Standard Deviation of the Average Fiber Diameter (SDAFD), Fiber Diameter Coefficient of Variation (FDCV), Comfort Factor (CF) and Staple Length (SL) was carried out in the Textile Fibers area of the Genetic Improvement Laboratory of the National University of Huancavelica using an OFDA 2000 optical analyzer. The five variables were evaluated by an analysis of variance (ANOVA) according to a randomized design, with a factorial arrangement of $2 \times 4$ that took into account the sex factor at two levels $(H=$ females, $M=$ Males) and the age factor at 4 levels. A Tukey test $(\alpha=0.05)$ was used to compare mean values. The Pearson correlation was used to evaluate correlations between textile characteristics. Data processing and analysis were carried out using software $R$ version 3.5.1.

\section{Results and discussion}

AFD values were $22.95 \mu \mathrm{m} \pm 0.47$ for females and $23.54 \mu \mathrm{m} \pm 0.40$ for males and were not statistically different ( $p>0.05$ ), suggesting that sex does not influence this characteristic (Table 1). This result is consistent with results reported in several earlier studies (Lupton et al., 2006; Ormachea et al., 2015; Quispe, 2016; Roque and Ormachea, 2018) as well as with Quispe etal. (2018) and Takashima et al. (2017), who found no significant sex-related differences in AFD values for highly valuable fleece from vicuñas, a related camelid.

However, age did significantly influence AFD values ( $p<0.05)$, as seen by increasing AFD values with age (Table 2 ), which again is similar to earlier findings (Roque and Ormachea, 2018; Machaca et al., 2017; Lupton et al., 2006; Quispe, 2016; Mueller et al., 2015; Laime et al., 2016; Quispe et al., 2018). Overall, older animals produced thicker fleece.

Both SDAFD and FDCV were not significantly influenced by either age or sex (Tables 1 and 2), which is similar to earlier findings of Machaca et al. (2017) and Quispe (2016; Tables 1 and 2)

Table 1

Average values and standard error for AFD, SDAFD, FDCV, CF, and SL as a function of sex for fleece from Huacaya alpacas raised at CRDC-Lacchoc

\begin{tabular}{ccccccc}
\hline Sex & N & AFD & SDAFD & FDCV & CF & SL \\
\hline Female & 47 & $22.95^{\mathrm{a}} \pm 0.47$ & $4.2^{\mathrm{a} \pm 0.12}$ & $18.69^{\mathrm{a}} \pm 0.41$ & $92.27^{\mathrm{a}} \pm 1.33$ & $13.13^{\mathrm{a}} \pm 4.05$ \\
Male & 33 & $23.54 \mathrm{a} \pm 0.40$ & $4.5^{\mathrm{a}} \pm 0.11$ & $19.57^{\mathrm{a}} \pm 0.35$ & $90.38^{\mathrm{a}} \pm 1.13$ & $11.81 \mathrm{a} \pm 3.45$ \\
\hline Total & 80 & $23.25 \pm 0.31$ & $4.43 \pm 0.08$ & $19.13 \pm 0.27$ & $91.32 \pm 0.87$ & $12.47 \pm 2.66$ \\
\hline
\end{tabular}

*The same letters in the same column indicate the absence of significant statistical differences $(p>0.05$, Tukey). 
Table 2

Average values and standard error for AFD, SDAFD, FDCV, CF, and SL as a function of age for fleece from Huacaya alpacas raised at CRDC-Lacchoc

\begin{tabular}{ccccccc}
\hline Age $(\mathrm{yr})$ & $\mathrm{N}$ & AFD & SDAFD & FDCV & CF \\
\hline 2 & 42 & $21.35^{\mathrm{a}} \pm 0.32$ & $4.32^{\mathrm{a}} \pm 0.08$ & $19.80^{\mathrm{a}} \pm 0.28$ & $95.72^{\mathrm{a}} \pm 0.92$ & $15.12^{\mathrm{a}} \pm 2.81$ \\
4 & 14 & $23.82^{\mathrm{b}} \pm 0.55$ & $4.64^{\mathrm{a}} \pm 0.15$ & $19.55^{\mathrm{a}} \pm 0.48$ & $88.69^{\mathrm{b}} \pm 1.55$ & $12.06 \mathrm{a} \pm 4.71$ \\
7 & 9 & $24.70^{\mathrm{b}} \pm 0.68$ & $4.55^{\mathrm{a}} \pm 0.18$ & $18.51^{\mathrm{a}} \pm 0.60$ & $88.49^{\mathrm{b}} \pm 1.92$ & $11.42 \mathrm{a} \pm 5.85$ \\
8 & 9 & $23.12^{\mathrm{b}} \pm 0.81$ & $4.31^{\mathrm{a}} \pm 0.22$ & $18.66^{\mathrm{a}} \pm 0.71$ & $92.34^{\mathrm{b}} \pm 2.30$ & $11.28 \mathrm{a} \pm 7.00$ \\
\hline Total & 80 & $23.25 \pm 0.31$ & $4.43 \pm 0.08$ & $19.13 \pm 0.27$ & $91.32 \pm 0.87$ & $12.47 \pm 2.66$ \\
\hline${ }^{*}$ The same letters in the same column indicate the absence of significant statistical differences $(\mathrm{p}<0.05$, Tukey).
\end{tabular}

The CF significantly decreased with age $(p<$ $0.05)$ consistent with previous studies (Ormachea et al., 2015, Vásquez et al., 2015; Roque and Ormachea, 2018). On the other hand, as with other studies, sex did not influence CF (Lupton et al., 2006, Quispe et al., 2009, Ormachea et al., 2015; Tables 1 and 2).

The lack of influence of sex on SL seen here is consistent with some earlier studies (Pinazo, 2000; Roque and Ormachea, 2018; Quispe et al., 2018; Takashima et al., 2017), but differs from the 2016 study by Quispe. SL was also not related to age, as per findings by Pinazo (2000), but this result differed from those of the 2016 and 2018 studies by Quispe, who found higher SL values for older animals.

Table 3 shows the Pearson correlations among the 5 characteristics examined for this study. There was a very high negative correlation ( $\left.r=-0.94^{\star *}\right)$ between the CF and AFD, wherein lower AFD (higher fineness) was associated with higher CF; this finding was consistent with previous reports (Lupton et al., 2006; Cervantes et al., 2010; Vásquez et al., 2015; Machaca et al., 2017). CF also had a negative correlation $(r=-0.75)$ with SDAFD such that low SDAFD (indicating more uniform fibers) had higher CF.

A negative but low correlation was seen between AFD and FDCV, which is similar to that reported by Quispe et al. (2009) and Vásquez et al. (2015), who obtained values of -0.09 and -0.03 respectively.

The correlation between FDCV and CF (0.02), was similar to that seen by Vásquez et al. (2015). Correlations between the other variables under study were not determined in this study.

Table 3

Pearson correlations between textile characteristics of fleece fibers from Huacaya alpacas raised at CRDCLachocc

\begin{tabular}{llllll}
\hline & AFD & FDCV & SDAFD & SL & CF \\
\hline AFD & 1 & & & & \\
\hline FDCV & -0.19 & 1 & & & \\
& 0.11 & & & & \\
SDAFD & $0.68^{\star *}$ & $0.59^{\star *}$ & 1 & & \\
& 0.00 & 0.00 & & & \\
SL & -0.12 & 0.17 & 0.02 & 1 & \\
& 0.33 & 0.15 & 0.88 & & \\
CF & $-0.94^{\star *}$ & 0.02 & $-0.75^{\star *}$ & 0.07 & 1 \\
& 0.00 & 0.84 & 0.00 & 0.55 & \\
\hline
\end{tabular}

\section{Conclusions}

The evaluation of textile characteristics of CRDC-Lachocc alpaca fibers in this study showed that these animals produce good quality fiber according to the current Peruvian Technical Standard (PTS) 231.301.2014 classification. Sex had no influence on any of the 5 characteristics studied. Age influenced only AFD and CF, wherein older animals had a higher AFD and a lower CF. Information about these factors will allow the effective selection of animals that produce the best fleece.

Meanwhile, the correlations between AFD, CF and SDAFD variables indicated that changes in one variable would likely also indirectly affect the other two.

Future research on characteristics of alpaca fiber should explore additional variables using current fiber analysis equipment and determine how they correlate with the factors examined in this study.

\section{Acknowledgments}

We are grateful for financial and logistical support received from the project "Genetic evaluation of characters of economic importance in Huacaya alpacas located in Pilpichaca district, Huaytara province, and Huancavelica region" that was financed using FOCAM-UNH resources.

\section{ORCID}

Rufino Paucar-Chanca (ID https://orcid.org/0000-00016820-6185

\section{References}

Cervantes, I.; Pérez-Cabal, M.; Morante, R.; Burgos, A.; Salgado, C.; Nieto, B.; Goyache, F. 2010. Genetic parameters and relationships between fibre and type traits in two breeds of Peruvian alpacas. Small Rumin Res 88(1): 611.

De Los Ríos, E. 2006. Producción textil de fibras de camélidos sudamericanos en el área altoandina de Bolivia, Ecuador y Perú. Organización de las Naciones Unidas para el Desarrollo Industrial (UNIDO). $52 \mathrm{pp}$.

INEI - Instituto Nacional de Estadística e Informática. 2012. IV Censo Nacional Agropecuario 2012 (CENAGRO, 2012). Lima: Resultados Preliminares. $91 \mathrm{pp}$.

Iñiguez, L.; Alem, R. 1996. Role of camelids as means of transportation and exchange in the Andean region of Bolivia. World Animal Review 86: 12-21. 
Laime, F.; Pinares, R.; Paucara, V.; Machaca, V.; Quispe, E. 2016. Características tecnológicas de la fibra de llama (Lama glama) Chaku antes y después de descerdar. Rev. Investig. Vet. Perú 27: 209-217.

Li, L.; Oddy, V.H.; Nolan, J.V. 2008. Whole-body protein metabolism and energy expenditure in sheep selected for divergent wool production when fed above or below maintenance. Aust. J. Exp. Agr. 48(5): 657-665.

Lupton, C.J.; McColl, A.; Stobart, R. 2006. Fiber characteristic of the Huacaya alpaca. Small Rumimant Research 64: 211-224.

Ormachea, E.; Calsín, B.; Olarte, U. 2015. Características textiles de la fibra en alpacas Huacaya del distrito de Corani Carabaya, Puno. Revista de investigación altoandina 17(2): 215-220.

Machaca, V.; Bustinza, V.; Corredor, A.; Paucara, V.; Quispe, E.; Machaca, R. 2017. Características de la fibra de alpaca Huacaya de Cotaruse, Apurímac, Perú. Rev. Investig. Vet. Perú 28: 843-851.

McGregor, B.A.; Butler, K.L. 2004. Sources of variation in fibre diameter attributes of Australian alpacas and implications for fleece evaluation and animal selection. Aust J Agric Res 55: 433-442.

Mamani, A. 2009. Correlación entre el diámetro, densidad y rizo de la fibra de alpaca Huacaya hembra, según región corporal. Tesis de Médico Veterinario y Zootecnista de la FMVZ de la UNA-Puno.

Manso C. 2011. Determinación de la calidad de fibra de alpaca en Huancavelica (Perú): Validación de los métodos de muestreo y valoración. Tesis de Ingeniero Agrónomo. Pamplona": Univ. Pública de Navarra. 121 pp.

Mayhua, P.; Quispe, E.C.; Montes, M.; Alfonso, L. 2011. Differences in fiber diameter profile between shearing periods in white Huayaca Alpacas. In: Pérez-Cabal M.Á.; Gutiérrez J.P.; Cervantes I.; Alcalde M.J. (eds) Fiber production in South American camelids and other fiber animals. Wageningen Academic Publishers, Wageningen.

Mayo, O.; Crook, B.; Lax, J.; Swan, A.; Hancock, T.W. 1994. The determination of Fibre Diameter Distribution. Wool Tech. Sheep Breed 42(3): 231-236.

Moore, K.E.; Maloney, S.K.; Vaughan, J.L.; Milton, J.T.B.; Blache, D. 2012. Rumen-protected methionine supplementation and fiber production in alpacas (Vicugna pacos). J. Anim. Physiol. Anim. Nutr. 97: 1084-1090.

Morante, R.; Burgos, A.; Gutiérrez, J.P. 2011. Producing alpaca fiber for the textile industry. In: Pérez-Cabal M.Á.; Gutiérrez J.P.; Cervantes I.; Alcalde M.J. (eds) Fiber production in South American camelids and other fiber animals. Wageningen Academic Publishers, Wageningen.

Mueller, J.P.; Rigalt, F.; Cancino, A.K.; Lamas, H. 2010. Calidad de las fibras de camélidos sudamericanos en Argentina. International Symposium on Fibers from South American Camelids.

Pinazo, R. 2000. Algunas características físicas de la fibra de alpaca Huacaya y Suri del C.E. La Raya. Tesis FMVZ-UNA, Puno.

Quispe, EC., Alfonso, L., Flores, A., Guillén, H., Ramos, Y. 2009. Bases para un programa de mejora de alpaca en la región altoandina de Huancavelica- Perú.

Quispe, E.C.; Rodriguez, T.C.; Iñiguez, L.R.; Mueller, J.P. 2009. Producción de fibra de alpaca, llama, vicuña, y guanaco en Sudamérica. $14 \mathrm{pp}$.

Quispe, E.C.; Ramos, H.; Mayhua, P.; Alfonso, L. 2010. Fibre characteristics of vicuña (Vicugna vicugna Mensalis). Small Ruminant Research 93(1): 64-66.

Quispe, E.C.; Poma, A.; Purroy, A. 2013. Características productivas y textiles de la fibra de alpacas de la raza Huacaya. Revista Complutense De Ciencias Veterinarias 7(1): 1 29.

Quispe, E.C. 2016. Componentes de varianza y repetibilidad de características productivas y textilesde la fibra en alpacas (Vicugna pacos) Huacaya criadas a nivel comunal. Archivos Latinoamericanos de Producción Animal 24(4): 217-224.

Roque, L.A.; Ormachea, E. 2018. Características productivas y textiles de la fibra en alpacas Huacaya de Puno, Perú. Rev. Investig. Vet. Perú 29: 1325-1334.

Solis, R. 1991. Tecnología de lanas y fibras animales especiales. Primera Edición. Facultad de Ciencias Agropecuarias. UNDAC. Cerro de Pasco. Perú. 676 pp.

Takashima, C.; Dionicio, A.; Arfagnini, M.; Saralegui, S.; Di Mauro, S.; Pacheco, C.; Marino, Patricia. 2017. Medición de finura y longitud de fibra de Vicuña obtenida en esquilas comunitarias en la Provincia de Jujuy, Argentina. Rev. Investig. Altoandin. 19: 187-194.

Vásquez, R.O.; Gómez, Q.O.; Quispe, E. 2015. Características Tecnológicas de la Fibra Blanca de Alpaca Huacaya en la Zona Altoandina de Apurímac. Rev Inv Vet Perú 26(2): 213-222.

Wang, X.; Wang, L.; Liu, X. 2003. The Quality and Processing Performance of Alpaca Fibres: A report for the Rural Industries Research and Development Corporation. RIRDC Putlication $\mathrm{N}^{\circ} 03 / 128$. Australia. $132 \mathrm{pp}$.

Wheeler, J.C. 2004. Evolution and present situation of the south american camelidae. Biological Journal of the Linnean Society 54(3): 271-295.

Wuliji, T.; Davis., G.H.; Dodds, K.G.; Turner, P.R.; Andrews, R.N.; Bruce, G.D. 2000. Production performance, repeatability and heritability estimates for live weight, fleece weight and fiber characteristics of alpacas in New Zealand. Small Rumin Res 37(3): 189-201. 